http://dx.doi.org/10.4314/ejotmas.v7i1-2.21

\title{
WOMEN AS AGENTS OF CONFLICT RESOLUTION IN FEMI OSOFISAN'S MOROUTODUN
}

\author{
*Rasheed Oshoke OGAKASON
}

\begin{abstract}
Over the years, there have been incidents of class struggle and secessionist agitations especially in developing nations such as Nigeria. This has drawn the attention of the government, security agencies and the ruling class who deem it a threat to the peace and unity of the nation. Many of such agitations are tackled using different strategies to manage the situations especially when it results to crisis and clash of interests leading to destruction of lives and properties. Nigeria, has recorded several incidents of agitations mostly from minority and separatist groups who see themselves as the oppressed and marginalized in the aspects of leadership, governance, power and unequal distribution of the nation's abundant wealth and resources. The literary world has contributed severally through the works of contemporary African playwrights such as Ngugi wa Thiongo, J.P Clark and Femi Osofisan, who have successfully woven their themes on issues such as conflict, emancipation, oppression and social struggle. This paper is premised on the theory of conflict resolution techniques and dispute management systems and textual analysis as its method. The paper examines the portrayal of women as agents of conflict resolution in Femi Osofisan's Moroutodun. It further draws the attention to the integral role of women in bringing about peace, positive change and development in the society. The paper concludes that women should be given a chance as men to contribute to peace-building and conflict resolution in the society.
\end{abstract}

Keywords: Women, Agents of conflict resolution, Moroutodun, Femi Osofisan, Nigeria

\section{Introduction}

The number of playwrights across Africa and in Nigeria specifically is on the increase. This situation is probably occasioned by the parlous

${ }^{*}$ Rasheed Oshoke OGAKASON is of the Department of Theatre and Performing Arts, Faculty of Communication, Bayero University, Kano, Nigeria

Email: rashmanson@yahoo.com 
state of affairs in the society. People want to air out their respective opinions but to some extent there is no best way to do so except through the dramatic means. Since the nature of the society is what brings forth a work of art, every society gets the kind of art it deserves. Obafemi (1996) posit that the works of Nigerian playwrights deal with contemporary social problems in Nigeria with the aim of raising mass awareness of a positive revolutionary alternative to the present decadence. Hence, it is clear that playwrights most times articulate historical, political, cultural, social and religious issues. As such, they make their stance known by debunking different vices in the society. In all aspects of human endeavour, disagreements are inevitable. It is bound to occur, especially during the course of human interaction. In spite of several considerations and actions geared towards establishing and maintaining peaceful co-existence and cooperation between governments, civil society organizations, faith and community-based organizations, conflict still lingers in the processes of human relations. Conflict is endemic to all social life. It is an inevitable part of living because it is related to situations of scarce resources, division of functions, power relations and role-differentiation. Because of its ubiquity and pervasive nature, the concept has acquired a multitude of meanings and connotations. Conflict is an outcome of behaviours. It is an integral part of human life. Whenever there is interaction there is conflict. Conflict means expression of hostility, negative attitudes, antagonism, aggression, rivalry, and misunderstanding. It is also associated with situations that involve contradictory interest between two opposing groups. It can be defined as a disagreement between two or more individuals or groups with each individual or group trying to gain acceptance of its view over others.

Women in indigenous societies have traditional peace making and peace building roles as they are involved in mediating and preventing conflicts within and between societies. Women's peace agency in these societies are reinforced by perceptions which stereotype women as natural peace makers, as being more specific than men and often symbolized as paragons of morality, sacredness, goodness and tenderness. Thus, in most indigenous societies, virtues of patience, tolerance, humility and subtle persuasiveness were seen as essentially female attributes which were reinforced through socialization patterns that promote women primarily as child-bearers good wives, caregivers, arbitrators of conflict and peace promoters in the family and community (UNESCO 2003). According to Chinkin (2003, p.15)

Women are deeply committed to peace-building and post-conflict reconstruction and have a unique and powerful perspective to bring to the negotiating table. Women often suffer disproportionately during 
armed conflict and often advocate most strongly for stabilization, reconstruction and the prevention of further conflict. Peace agreements, post conflict reconstruction and governance have a better chance of long-term success when women are involved.

Furthermore, establishing sustainable peace requires transforming power relationships, including achieving more equitable gender relations. Strickland and Duvvury (2003) assert that women's peace groups in Uganda, for example, have used conflict resolution training to successfully reduce the level of violence in their communities. In the face of strong resistance from male leaders, women have established cross-community coalitions to open up dialogue and are operating centres to rehabilitate former girl abductees and child soldiers.Women can play an important role in the prevention and resolution of conflicts. Empowering women in conflict situations would likely help prevent gender-based violence such as the abominable crime of rape, forced pregnancy, sexual slavery and others.

Hence, dramatists as a member of the society who also share or witness the occurrence of certain changes have the liberty to portray such happenings through literary works, especially ones that have something to do with class struggle. Such writers present women either as agents of social change or as submissive objects. While conservative dramatists do not give women high regards and present them as having very little power to influence positive change, the perception of writers such as Femi Osofisan in a dramatic work, Morountodun, is different.

\section{Concept of Conflict Resolution}

Over the years, waves of conflict and violence have been ongoing throughout Africa in diverse neighborhoods. Several provinces have been submerged in violent fits of ethnic insecurity, violence and genocide. It important to note that wherever humans exist conflict will abide. Sadly, conflict has become part of human life, but one thing about it is that it has a transitory nature. An understanding of the meaning of conflict would contribute immensely in its resolution. Tenacious eruptions of conflict led to the conception of preventive measures and the management of conflicts. Miller (2003, p.8) posits that conflict resolution is "a variety of approaches aimed at terminating conflicts through the constructive solving of problems, distinct from management or transformation of conflict." For Mial and Woodhouse (2001), by conflict resolution, it is expected that the deep-rooted sources of conflict are addressed and resolved, and behaviour is no longer violent, nor are attitude hostile any longer, while structure of the conflict has been changed. Mitchel and Banks (1996, p.21), conceives it as: 


\begin{abstract}
An outcome in which the issues in an existing conflict are satisfactorily dealt with through a solution that is mutually acceptable to the parties, self-sustaining in the long run and productive of a new, positive relationship between parties that were previously hostile adversaries; and process or procedure by which such an outcome is achieved.
\end{abstract}

Conflict resolution is the same as argument about particular issues underlying a dispute. If the parties to a disagreement can agree on an outcome that is conjointly acceptable, then conflict would be resolved. Resolution ensues through a sequence of diverse happenings intensely and usually with various hindrances along the way. It is a progression of letting go of conflict and of gaining the energy, lesson and growth that conflict has to offer. Conflict resolution is a range of processes aimed at alleviating or eliminating sources of conflict. The term 'conflict resolution' can be used interchangeably with 'dispute resolution.' This process of conflict resolution can include but not limited to negotiation, mediation and diplomacy.

\title{
The Role of Women in Conflict Resolution in Nigeria
}

The bitter experiences of women in times of war often make them strong adherents of peace building and constitution making for conflict resolution. However, women's roles in and contributions to conflict resolution are underutilized or wholly ignored in mainstream peace building and constitution making processes. In many war situations women have used their different roles to try to minimize the effect of violence if not put out wars. In Nigeria, women in an effort to participate in conflict and peace resolution, organized interfaith activities in Kaduna. One of such activities is interfaith dialogue. Also, a book about conflict and peace resolution was launched July 5th 2011 at the Women's Multipurpose Centre, Kaduna. This is because women realize the importance of their participation in peace building processes in the country. Other activities include joint press conference and visits to the camps of displaced people in different towns in the state. After successfully implementing the some of these activities they organized a sensitization seminar which was attended by policy makers and representatives of various civil society organizations in the state and beyond. The main focus of the seminar was to highlight the role of women in peace building.

Conflict resolution has to do with settlement of conflict that may have already taken shape. This can be by reconciliation or alienation. Conflicts should be resolved before they get to the destruction phase. 
Conflict resolution performs healing functions in societies. Peters (2006) opines that conflict resolution is how to control or manage an existing conflict so that it does not escalate, thereby leading to chaos, crisis and war. Peace building as presented by Maiese (2003, p.3) "is a process that facilitates the establishment of durable peace and tries to prevent the recurrence of violence by addressing root causes and effect of conflict through reconciliation, institution building and political as well as economic transformation." Women should be involved in peace building because they have a unique understanding of community needs. Women in their homes have the political will to stop their husbands and sons in participating in conflicts. Non-governmental organizations (NGOs) in Bauchi State integrate peace and conflict resolution in their activities with women groups in order to educate them on the need to be up and doing in the pursuit of peace in their communities.

Women can, therefore, help outline the causes of conflicts and how to resolve them. The Egba women's movement of the early 1920s to the 1950, the Ogharefe Women Uprising of 1984 and many others reflect times when Nigerian women mobilized and exercised their collective power to resolve conflict and build peace. Idris and Habu (2012) noted that these women commanded important position in conflict resolution rituals and it is argued that if given the chance they can do the same to the greater glory of peace and tranquility in contemporary society. Consequently, Nigerian women are resources of peace building and conflict resolution in the country, their role in peace building and conflict resolution has been argued to be largely incipient.

\section{Theoretical Framework}

This paper is premised on the theory of conflict resolution techniques and dispute management systems. The theory has its roots in the "Judeo-Christian culture that developed in Europe and North America and was particularly shaped in the twentieth century by the first and second World Wars" (Stewarts, 2006, p.5). The proponents of the theory included philosopher and sociologist George Simmel (18581914) and Gestalt (influential on social psychology) and psychologist Kurt Lewin (1890-1947). The theory attracted interest, grew and spread during the 1970s and 1980s. Roy et al. (2010) are of the view that the practice of peace-building following terrible violence became particularly important after the Cold War ended. The conflict resolution technique is now highly diverse both in theory and practice. According to Brinkerhoff and Crosby (2002, p.205): conflict resolution techniques stimulate stakeholder participation, encourage policy ownership, and 
build institutional capacity. Ultimately; these techniques are forwardlooking mechanisms, seeking to bolster a transformation of the situation from the negative to the positive.

Roy et al. (2010, p.45) corroborate that the theory has "ideas and practices that are applicable to transforming entrenched conflict, negotiating mutually acceptable agreement, and building constructive relationships after a destructive encounter". This is observed in the activities of Moremi in her quest to bring the rebels to book as well as the approaches she took to address the conflicts and engender peace in the society. Brinkerhoff and Crosby (2002) further assert that conflict resolution techniques can be categorized into four basic mechanisms, namely: confidence building, joint problem-solving, mediation and negotiation. Confidence building mechanisms are used to develop trust and confidence among parties that may be in conflict or that need to enhance their cooperative bonds. This is usually a step-bystep process in which graduated unilateral concessions are made by one party and in-kind reciprocation is sought from the other parties. By indicating goodwill and an honest desire to cooperate, confidence building mechanisms often lay the foundation for additional conflict resolution methods. Joint problem-solving involves the joint search for ways to deal with a dispute that divides the parties or a problem that they both need to resolve to mutual satisfaction. Brinkerhoff and Crosby (2002, p. 209) point that:

Interactive joint problem-solving is usually conducted in workshops that are facilitated by third parties who set the terms of reference and agenda for the sessions. In these workshops the parties can share differing perspectives, think and problemsolve together, find opportunities for creative idea generation, and overcome deeply rooted conflicts through dialogue. Success in problem-solving often leads to the commencement of negotiations.

Mediation involves third parties who simplify a process of dialogue among the principal protagonists. This is a feasible substitute if the actors in a conflict are willing to find a resolution, but require the services of a third party to help them to influence it. Third parties can be governmental officials who carry the weight, power and influence of their governments into a mediation effort, or they can be nongovernmental, unofficial mediators, practicing what has become known as track-two diplomacy. Mediation can be a catalyst to begin dialogues or can be used to overcome a standoff within a negotiation. 
Intercession is a process of joint decision-making in which the principal parties seek to accommodate their conflicts of interest and develop a mutually acceptable solution. Also, in mediating in conflict situations, Titubi sacrificed herself by acting as a decoy and also an agent for conflict resolution to ensure peaceful co-existence between the elite and peasants class. Negotiation typically seeks to achieve integrative solutions, in which an outcome is found that satisfies and reconciles the conflicting interests of all sides, but none of the sides view themselves as a clear winner or loser. All the parties usually benefit in such integrative agreements.

\section{Background of the Playwright Femi Osofisan}

Winner of the first Association of Nigerian Authors drama prize in 1983, Femi Osofisan is a well-known playwright in Nigeria and beyond. He was born in a farming village named Erunwon in Western Nigeria in 1946. When independence arrived in 1960, Osofisan hoped that it would soon be followed with its promise of planned decolonization. However, from 1962 to 1966 the country was raged with political instability which came to an abrupt end with two successive military regimes that brought about the Nigerian Civil War that lasted till early 1970. While Nigeria was going through hard times and new developments, Osofisan took an interest in French, and began writing his early plays severely criticizing self-aggrandizing politicians. Besides his resentment of cultural estrangement which was a direct consequence of colonialism, it was also his longing to define and revive pre-colonial African consciousness that motivated Osofisan.

However, his most remarkable achievement is his ability to stay in touch and in tune with the tradition he grew up with, the rituals of Esu and Orunmila in Yoruba. Overall, a variety of forces enabled Osofisan to shape his own unique vision of drama, based on a philosophical foundation that affirms classical Africa's contribution to myth, legend, folklore of the world civilization, long before Greeks started the secularization of theatre through an adaptation of religious festivals. He continues to write and publish. He is, perhaps, the most performed playwright in Nigeria today (Okur, 1998, p. 1). As a matter of fact, Osofisan's work clearly reflects the impact of Yoruba traditions and its folklore. His pursuit of a "rendezvous with history" renders him capable of defining a different conception of art, and the artist's relationship to his society as inevitable. Osofisan joins the group of African writers and thinkers who believe in art's functional, committed, and collective attributes. 


\section{Synopsis of Moroutodun}

Morountodun (I have found a sweet thing) is based on the legend of Moremi of lle-Ife. It dramatises the Agbekoya peasant uprising in the then Western Nigeria in 1969. In the play, Osofisan recreates the Moremi myth of struggle and injustice in order to meet the contemporary need of the Nigerian society; peasants struggle, therefore, is the main conflict of the play. This conflict is between a peasant community in and an oppressive state authority. The peasants are fighting to surmount the forces of exploitation and injustice perpetuated on them by this ruling class. This conflict is causes a serious concern for the authority which finds it increasingly difficult to contend. Osofisan has recreated the myth of Moremi in this play to portray how such cultural heritage could be employed to serve contemporary social need. The play opens in a rather non-formal rehearsal setting in the "Dressing area" with "a flurry of activity: actors making up, trying costumes, reading script, rehearsing gestures, miming some of the actions in the play. Director then emerges to give a resume of the play, which is about the Agbekoya uprising, in which ordinary farmers rose up and confronted the state. However, before the play really starts, Titubi, the 'spoilt' daughter of Alhaja Kabirat, the head of the market women and storms into the theatre with her group to disrupt it.

The activities of the theatre group in portraying the predatory nature of the bourgeoisie, which her mother represents, might have become a big threat. She is arrested in the process by Superintendent Salami, symbolising the repressive state apparatus, who challenges her on putting up a showdown on the peasant revolt currently raging in the area against her class instead of proving her gallantry in the theatre and seeking to destroy it. He succeeds in convincing her on the need to crush the rebellion, and wins her alliance. Thus she decides to collude with the police by serving as a decoy to infiltrate the peasants' territory to trap their seeming intractable leader. This turns out as Osofisan's rather recreation of the ancient Yoruba mythology by invoking the myth of Moremi, as he links Titubi with the legendary Queen of Ile-Ife who risked her life to save her people from the menace of Igbo by serving also as a decoy.

The ploy is to put Titubi in prison where she will be freed by the rebelling farmers when they attack the prison to release their members who are captured by government forces. Titubi sets upon this 'heroic' mission. The rebelling farmers eventually attack the prison and free her with their captured members. She follows them to their camp, settles and interacts with them, only to discover to her disgust their plights for taking up 'arms' against the state. Rather than betray the farmers as planned she veers and subscribes to their cause and joins forces with them, "committing class suicide." She becomes rechristened as 
Morountodun, meaning "I have found a sweet thing", and transfigures into a spokeswoman for the oppressed.

\section{Women as Agents of Conflict resolution in Moroutodun}

The play opens with a central female character Titubi, daughter of Alhaja Barakat who is impressed and wants to trade the part of her ancient mentor, the legendary Moremi who embarked on a dangerous quest to set her people free from oppression and degradation. Laying much emphasis on Titubi, Osofisan virtually depicts an intelligent and wise woman who is willing to sacrifice all she has just to ensure there is peace in the land by accepting to be used as a decoy, by allowing the rebels to capture her in order to bring the rebellious militias into captivity:

Titubi: Salami! (SUPERINTENDENT stops, without turning round.)Salami, suppose I do volunteer?

Superintendent: (Turns now) What?

Titubi: I said, suppose I offer to fight the peasants?

Superintendent: You are not finished with your pranks for tonight?

Titubi: It's their leader you have not been able to capture, isn't

it? That's why the war drags on?

Superintendent: Well-

Titubi: (Hard) Yes or no?

Superintendent: Well, yes.... And no. Their leader proves

elusive, but-

Titubi: But?

Superintendent: He may not really exist.

Titubi: He may not exist! A phantom leader!

Superintendent: I mean....there may not be just one leader, maybe a group of Leaders....

Titubi: But someone leads that group?

Superintendent: Actually-

Titubi: You are a liar, Salami. You know he exists. And you know his name. You admitted it in your interview with

the press last week.

Superintendent: Okay, so I admitted it. They call him Marshall.

Titubi: I can bring him to you. (14-15)

This clearly shows the strong will of women in taking difficult decisions, possibility of embarking on dangerous quests, sacrificing 
things that are most pleasing to them and also the courage to foster conflict resolution without fear and considering its implications. No matter what it will take them, they still believe that they can do it despite criticisms and undermining by people in the society.

The play also captures the bravery of women in promoting conflict resolution as Titubi stands her ground to be used as a bait to bring down the deadly group against all odds. This is portrayed in the enactment of Alhaja, the mother of Titubi who attempted to stop her daughter with all her might and power but her daughter stood her ground despite the immense love they both share as mother and daughter. Titubi believes that if the legendary Moremi can embark on such quest she too can do it successfully. This demonstrates the ideology of women taking legends and heroes as mentors that they see as strong and encouraging forces to drive their zeal for engaging in matters of conflict. This is captured in the lines below.

Alhaja: Stop him, I say! In the name of Allah!

Superintendent: Allah, madam, is always on the side of those who do more than just fold their arms and watch. We needed a brave woman. Your daughter volunteered. She is to be commended.

Alhaja: (Cowed now) you think that if she... if Titu follows this crazy plan.?

Superintendent: Your daughter has the best credentials for this kind of job. She is willing to do it, and she is richly endowed. Pretty, sensual, daring, and with quite a reputation with men, if my information is correct?

Titubi: Thank you....

Superintendent: Above all, she's not known to be even remotely connected with the police.

Alhaja: And you think you can do it, Titu?

Titubi: I will do it, mama. One woman did it before.

Alhaja: A woman?

Titubi: Moremi, Have you forgotten?

Alhaja: (Clinging to her) My poor doll!

Titubi: Wipe your tears, mama. I will come back safe, you will see.And the war will soon be over.

Superintendent: Good. If you have made up your mind.

Titubi: Nothing can stop me now. (24) 
On her successful arrival in the rebels' camp, she proved herself useful as she is seen rendering assistance to the rebels through health care services by voluntarily serving as a nurse to the wounded victims during and after the fight that ensued between the rebels and the police even though she was also injured in the process:

Baba: (Nodding) Hm-hmHow is she? (Indicating TITUBI)

Marshal: A flesh wound. She will survive.

Baba: I am relieved. She has been useful to us.

Marshal: So you all say.

Baba: We needed a nurse badly, and

Marshal: (Ironically) And she served the purpose.

Baba: More than. She surpassed even my expectations. (They Both draw slightly aside) there were nights she didn't sleep at all, nursing the wounded. (42)

This attitude shows that even when a woman is used as a decoy to promote change she still has the capacity to show mercy to those she is sent to bring down. Rather than being rude to the rebels she made herself important and useful by catering for the wellbeing of the rebels. This depicts the soft heartedness and kindness of women in the process of fostering emancipation in the society. Titubi, having gone through thick and thorns in the rebel's camp was able to conquer her mission successfully by bringing the notorious King pin of the rebels "Marshal" but in the process she discovered the hidden truth behind the struggle and faction between the rival groups, whereby her experience unraveled the evil doings of the corrupt elites who pose as the states and protectors of the law. This is depicted in the lines below.

Titubi: I said I would do it, didn't I?

Alhaja: My daughter! (She bursts out crying.)

Superintendent: You did it! By God! You are Moremi!

Titubi: (To Marshal) Sit down. But don't try anything.

SUPERINTENDENT: So this is the Marshal!

Titubi: I went, and returned, triumphant. Like a legend. You didn't believe me, did you? But mother, I did it!

Alhaja: My daughter! (Still sobbing.)

Titubi: But I am not the same as I went away. A lot has happened. And I have a long story to tell you.

Superintendent: I am dying to hear it. 
Titubi: Then sit down. For it will be long. I lived among the farmers, just as you sent me. And this is what happened....(60)

Although, the above lines speak to her victorious mission but her encounter and experience was a re-enactment. The following lines portray the fact that she had discovered a hidden truth with regards to the struggle:

Titubi: That was when I began to ask questions. Questions. I saw myselfgrowing up, knowing no such sufferings as there. With always so much to eat, even servants feed their dogs...yet here, farmers cannot eat their own products, for they need the money from the market. They tend the yams but dare not taste. They raise chickens, but must be content with wind in their stomach. And then, when they return weary from the market, the tax man is waiting with his bill...it could not be just jiggling coins. And when we sleep, coiled springs, soft foam and felt receive our bodies gently. But I have lived in the forest among simple folk, sharing their pain and anguish. (66)

However, the play further brings out the true self of Titubi who thought herself as the legendary Moremi after discovering that Moremi had fought selflessly at the service of her own people. This is captured in the lines below:

Titubi: Keep still, Salami. My hands are jittery on the trigger, and I won't like to kill you in error.

Superintendent: (Raising his hands quickly) All right, all right, girl just keep calm.

Alhaja: (Trembling with shock) Titu! Titu! Please don't do it. You are my only daughter. They will kill you.

Titubi: (Laughs, but shrilly: she's overstretched) Mama, our life itself is not important. Nor all these glittering tinsels we use to decorate it...Ask your friend Salami. He knows the truth now. In another week, he will be asking to negotiate. He won't be in such a hurry to order the

massacre of children....for there's no way you can win a war against a people whose cause is just. As long... (She's beginning to falter now)...as...long as the law remains...the privilege of a handful of powerful men...ah, I am tired...Marshal!..you didn't believe me, did you? You never believed I was Sincere?.(70).

Marshal: Titu, I-

Titubi: Take the gun. (She hands it over to him.) Let a new life begin. 
This makes it feasible to portray African women as emotionally strong when it comes to handling sensitive issues and making them trend on the platform of truth and abide by it no matter its implications; they are wont to call a spade a spade. However, this takes us to the end of the play as Titubi, instead of betraying the farmers as planned, she veers and joins forces with them as she is seen handling over the gun to Marshal. She is rechristened as 'Morountodun.' She earns this heroine status for her ability to be able to bring peace and mutual understanding among the warring classes. Here, Osofisan reveals the highest form of conflict resolution a woman can bring to the society. This is seen through the patience, wisdom, endurance and hard work that is embedded in the womenfolk in engendering peace even in times of difficulty when hope is lost.

\section{Conclusion}

This study has observed that the Femi Osofisan as a plawright is of the view that women should be given a 'voice' as well as equal rights as men especially in areas of contributing to the peace and conflict resolution in the society. It is important to note that women as portrayed in Morountodun can act as agents or catalyst for conflict resolution through active participation by involving and contributing to the developmental processes of the society regardless of how the society view them.

\section{References}

Banks, O. (1986). Becoming a feminist: The social origins of first wave feminism. London: Harvester Press Ltd.

Brinkerhoff, D. W. \& Crosby, B. L. (2002). Managing policy reform: Concepts and tools fordecision-makers in developing and transitioning countries, New York: Kumarian Press.

Chinkin, C. (2003). Peace agreements as a means for promoting gender equality and ensuring the participation of women. New York: United Nations.

Crosby, B. (1991). Strategic planning and strategic management: What are they and how are they different?. (IPC technical note No. 1). Washington, DC: Management Systems International Inc.

Maill, H \& Woodhouse, T. (2001). Contemporary conflict resolution: The prevention management and transformation of deadly conflicts. Cambridge: Polity Press.

Miller, C. A. (2003). A glossary of terms on conflicts: Concepts in peace and conflict studies. Geneva: University for Peace. 
Obafemi, O. (2009). Contemporary Nigerian theatre. Lagos: Centre for Black and African Arts and Civilization.

Okur, N. (1998). Ritual, tradition and reconstruction in contemporary Nigerian drama: Femi

Osofisan and Tess Akaeke Onwueme a dramatic analysis in Afrocentricity. Retrieved 20 May 2019, from https:// www.academia.edu.

Osofisan, F. (1982). Morountodun and other plays. Ikeja: Longman Nigeria Limited.

Peters, I. (2006). Conflict management. A paper presented at a workshop on conflict resolution organized by Nigeria Network of Non-Governmental Organizations (NNGO), held at the Institute of Medical Research and Training, Biode Building, College of Medicine, University College Hospital (UCH), Ibadan.

Roy, B. et al. (2010). A conversation between conflict resolution and social movement scholars. Conflict Resolution Quarterly, 27(4), 353-354.

Stewarts, M. (2006). Conflict resolution theory. Retrieved 20 May 2019, from http://www.palestineisraelsolutions.blogspot.com

Strickland, R. \& Duvvury, N. (2003). Gender equity and peace building: From rhetoric to reality: Finding the way. Washington D.C. International Center for Research on Women.

Thakore, D. (2015). Conflict and conflict management. IOSR Journal of Business and Management, 9(3), 7-16.

United Nations Educational, Scientific and Cultural Organization. (2003). Women and peace in Africa: Case studies on traditional conflict resolution practices. Paris: UNESCO.

Uwatt, B. E. (2002). Theatre of beast: The dramaturgy of Ola Rotimi. Ibadan: Sam Bookman. 